\title{
China's Experimental Pragmatics of 'Scientific Development' in Wind Power: Algorithmic Struggles over Software in Wind Turbines
}

\author{
JULIA KIRKEGAARD
}

\begin{abstract}
This article presents a case study on the development of China's wind power market. As China's wind industry has experienced a quality crisis, the Chinese government has intervened to steer the industry towards a turn to quality, indicating a pragmatist and experimental mode of market development. This increased focus on quality, to ensure the sustainable and scientific development of China's wind energy market, requires improved indigenous Chinese innovation capabilities in wind turbine technology. To shed light on how the turn to quality impacts upon the industry and global competition, this study adopts the micro-processual, socio-technical, relational and empiricist lens of Science \& Technology Studies (STS). It illustrates how Sino-foreign collaborative relations around the core technology of software (in control systems and simulation tools) have become politicised, and how controversies unfold over issues associated with intellectual property rights (IPRs), certification and standardisation of software algorithms. The article concludes that the use of this STS lens makes a fresh contribution to the often path-dependent, structuralist and hierarchical China literature, offering instead a possibility- and agency-filled account that can shed light on the dynamics of China's fragmented governance and experimental market development.
\end{abstract}

Keywords: experimentation, software algorithms, wind power, turn to quality, Science \& Technology Studies

\section{Scientific Development in Chinese Wind Power through Software Algorithms}

Today, China boasts the largest wind power market in the world when measured in installed capacity (GWEC 2016; Kirkegaard 2015; Lewis 2013; Korsnes 2014, 2015; Chen et al. 2014). What is even more remarkable is how this position has been achieved within less than a decade. Growing from almost nothing in 2004 (with 0.8 GW installed), China 
installed $145 \mathrm{GW}$ wind power by 2015, accounting for 46.6 per cent of global installations in that year, and boasting 33.6 per cent of global cumulative installations (GWEC 2016: 32). This is a remarkable success story.

The other side of the coin, however, reveals an imminent quality crisis in China's wind power market, both onshore (Kirkegaard 2015; Kirkegaard and Caliskan, forthcoming) and offshore (Korsnes 2015). The quality crisis results largely from China's policy focus on low prices and quantitative growth in the industry's founding years, e.g. targets were set only for installed capacity (Gigawatt/GW), rather than for actual generated electricity (Gigawatt hour/GWh), which would have helped ensure higher quality as reflected in a lower cost of energy and higher energy output. The focus on rapid upscaling and price-competitiveness rather than long-term turbine performance has, among other things, resulted in under-performing wind turbines, lack of reliability and high rates of grid curtailment (i.e. the grid company forces wind farm operators to down-regulate or even stop production to reduce the destabilising impact on the power grid) (Klagge et al. 2012; García 2013; Li et al. 2014; Cherni and Kentish 2007; Bloomberg 2012; Li 2010; Liao et al. 2010; Yu et al. 2009). It seems that 'a quick industry build-up comes with a price' (Korsnes 2014: 195).

The development of China's wind power market can, according to a Chinese wind power specialist and government advisor, be explained through the Chinese military metaphor of the 'Human Wave Attack' (renhaizhanshu) (Interview in Kirkegaard 2015: 373-374), which denotes a strategy of frontal attack with densely concentrated infantry formations that run against the enemy line with the aim of overrunning the defenders through sheer scale and surprise (Interview in Kirkegaard 2015: 373-374). As such, China has flooded the wind power market with low quality turbines through what may be termed a 'Wind Turbine Wave Attack'. This is now shaking up China's wind power market as well as global competitive dynamics (Kirkegaard 2015). The resulting quality crisis from the wind turbine attack has in turn recently led to radical intervention from the Chinese Government to get the Chinese wind turbine industry market back on track. This takes the form of new targets for generated electricity, new and higher certification and standardisation requirements, gradual fine-tuning of price-levels and feed-in-tariffs, an increased focus on industrial upgrading and indigenous innovation in wind turbine core technologies such as software, and increased centralised control of new wind farm approvals to coordinate growth and raise 
the focus on quality (Korsnes 2014, 2015; Kirkegaard 2015; Kirkegaard and Caliskan forthcoming; Lewis 2013; García 2013). Reflecting China's fragmented authoritarianism (Lieberthal 2004; Mertha 2009; Korsnes 2014; Lema and Ruby 2007), the Chinese State thus seems to have been steering and fine-tuning the industry in an oscillating movement between centralised control and local freedom:

Now the second wave is coming, now that they [the Chinese government] have realised that it may not be the best quality... it's cheap, the prices have been pushed all the way to the bottom, which has been hard for the Western manufacturers, because they have not been able to sell their turbines [...] So, then around one, one and a half year ago or so [i.e. around year 2011/2012], then the government intervened and changed its standpoint. Okay, we have to recognise that they are not good enough. They [the turbines] are not as they are supposed to be, so we need to...focus on quality [...] and that's kind of the situation that we are facing now. (Interview with foreign control system supplier in Kirkegaard 2015: 374)

As a political response to how the quality crisis in Chinese wind power could have potentially delegitimised China's wind power market and had called into question China's overall ability to fulfil its vision of 'sustainable' and 'scientific development' on its path towards a Harmonious Socialist Society (shehui zhuyi hexie shehui), the Chinese state navigates the development of the Chinese wind power market (Korsnes 2014) through an imminent 'turn to quality' (Kirkegaard 2015). One Chinese expert on wind power describes this pragmatic and experimental mode of governance in positive terms: allowing a quality crisis to emerge 'will force us to have the solutions'. Conversely, 'if the problem had not appeared, nobody would have considered that [a potential problem]. In this lens, 'to learn from practice is much better than learn[ing] from theory or learn[ing] from imagination [...] It's the Chinese way [...] In China, [it's] very strange, maybe different from Europe, but in China every... we first do it - then to solve it!' (Interview with Chinese wind power expert and government advisor in Kirkegaard 2015: 352).

This pragmatic approach to industry development through experimentation may be explained by the way in which the very notion of 'pragmatism' translates in Chinese as shiyan zhuyi, which literally means 'experimentalism' (Heilmann 2008: 18). Rather than offering a dualist account of either success or failure, this article inquires into whether the development of China's wind power market can tell a broader story about China's particular political economy of greening and industrial upgrading. It also asks whether a constructivist lens may be helpful in shedding light on this issue. 
China's heterogeneity and decentralised experimentation under hierarchy in China's matrix muddle is also what has been claimed to make China 'unique in being persistently uninstitutionalized' (Lieberthal 2004 qtd. in Breznitz and Murphree 2011: 11). This article seeks to qualify and contribute to the China literature on fragmented authoritarianism and variegated capitalism. Both have facilitated the rapid growth in Chinese wind power, but have also allowed for potentially self-disruptive quality issues. Through a constructivist case study on China's wind power market, this article traces Sino-foreign relations around the core technology of software algorithms in main control systems and design simulation tools, which have become constituted as a critical means to realising China's ambitions of scientific development in wind power during the imminent turn to quality. By illustrating how core algorithms are producing concerns and struggles over IPRs and standards amongst Chinese and foreign actors in the Chinese wind turbine industry, the article helps shed light on how market development, technologies and industrial relations are entangled in politics, particularly in the developmental context of China's strategic and state-controlled power sector. By showing how micro-level processes and seemingly mundane material entities such as software algorithms, can tell a broader macro-story of China's scientific developmentalism ${ }^{1}$ (kexue fazhanguan), it seeks to illustrate how a constructivist lens may qualify our understanding of some of the shifting dynamics of global competition and China's political economy.

\section{Method and Moving Towards a Constructivist Account}

To provide this kind of 'micro-level' story, which can reflect the broader macro-story of China's development and contribute to the extant China literature (e.g. Lieberthal 2004; Peck and Theodore 2007; Zhang and Pack 2014), this article draws on the pragmatist and relational, constructivist lens within STS, in particular the Anthropology of Markets and Actor Network Theory (e.g. Callon and Caliskan 2009; 2010; Callon 1998; Latour 2005). These offer an agency-filled and micro-processual relational lens by following the algorithms and relations configuring around them. By 'following software algorithms' and mapping some of the socio-technical controversies they produce, the article utilises the Mapping Controversies approach within STS (Yaneva 2012). Pursuing an explorative line of inquiry, the idea to follow entangled controversies regarding IPRs and certification and standardisation of software algorithms only emerged gradually in the doctoral research 
on which this article draws (Kirkegaard 2015). Core software algorithms were persistently mentioned in the interview data as critical to quality, and to China's turn to quality. They were also mentioned in Chinese policies and plans as critical components of China's indigenous innovation capabilities and its alignment with the doctrine of scientific development. By mapping controversies around software algorithms, the article sheds light on the sometimes contested roles and positions of Sino-foreign industrial relations, and how these are constituted by and co-constitute a Chinese experimental pragmatics of industrial development.

The article is based on semi-structured interviews conducted during eight months of ethnographic fieldwork undertaken in China for my doctoral research (in a period between September 2011 - September 2013). Additional follow-up fieldwork was undertaken in 2015 and 2016. Interviews were conducted in English, Chinese and Danish, with people from many different types of organisations, e.g. Chinese and foreign wind turbine manufacturers, component suppliers, universities and research institutes, industry associations, related ministries, China State Grid, design/consulting companies, think tanks, certification bodies, test laboratories and finance institutions. Additional insights were elicited at industry conferences and exhibitions. Interviewees were mostly identified through the snowballing method, and the interviews were transcribed to provide a basis for detecting patterns of discourses and narratives in the data as well as for mapping issues and controversies. Beyond the primary data, the article makes use of Chinese policies, regulations, and Five- and Fifteen-Year Plans on renewable energies, wind power, science and technology and (indigenous) innovation as a foundation for detecting narratives that together constitute what may be termed a 'socio-technical imaginary' (Jasanoff and Kim 2009; Korsnes 2015) of China's path towards a Harmonious Socialist Society through scientific development.

\section{Socio-technical Struggles in Chinese Wind Power}

The following empirical analysis provides an account of how China's wind turbine industry is framed and entangled within an overall doctrine of scientific developmentalism. This leads to a mapping of sociotechnical controversies over issues of IPRs and standardisation around software algorithms. 


\section{Role of Software Algorithms in the Scientific Development of Wind Power}

China's wind power industry has emerged within a comprehensive list of supportive plans, laws, policies, and regulations. Apart from a supportive legal framework directly related to renewable energies and wind power in particular (e.g. the influential Renewable Energy Law 2005/2006), China's policies and plans for the scientific and technological development of wind power have exerted an indirect and sometimes direct influence on the development of China's wind power market, as well as on the configuration of Sino-foreign industrial relations. Explicitly based on the ideological doctrine of scientific development, or the so-called 'Scientific Outlook on Development'(Fan 2006; Christensen 2013), the $12^{\text {th }} 5$ YP for the Scientific and Technological Development of Wind Power (2012) (hereafter, 5YP S\&T Wind Power) is the first plan dedicated plan to the scientific and technological development of wind power. Thus, wind power is discursively coupled with the Chinese narrative of the 'Harmonious Socialist Society'.

A 'harmonious society is the objective and scientific development is the method to reach it' (Fan 2006: 709-717). In China, 'a comprehensive, programmatic idea of sustainability' (Christensen 2013: 90) has been promoted, involving a series of intricately linked discourses on sustainable development and scientific development towards a 'harmonious socialist society'. Sustainable and scientific development is coupled directly with industrial upgrading and indigenous innovation (zizhu chuangxin, literally: homebred or independent) capabilities within core technologies in the quest to reduce dependence on Western technology and climb up the global value chain (Kirkegaard 2015; Christensen 2013: 89; Breznitz and Murphree 2011). Such 'scientific developmentalism' reflects a 'new economic mode' (Christensen 2013: 83) in China's gradualist transition process. The 'Scientific Outlook on Development' can thus 'be seen as the substantiation of the milestones of the second phase in the national tale' (Christensen 2013: 86), as China attempts to move from an extensive economic growth model towards an intensive economic growth model (Former president Jiang Zemin 1995: 8 qtd. in Christensen 2013: 83).

On the path towards China's sustainable and scientific development, indigenous innovation capabilities within core technologies increasingly play a critical role. Accordingly, a host of plans, regulations, and policies on innovation and S\&T have been issued. In particular, the State Council's (2006) Fifteen-year National Plan for the Development 
of Science and Technology in the Medium and Long Term (2006-2020) (hereafter, MLP S\&T) has been influential. Linking the notion of scientific development directly to China's rejuvenation and the construction of a harmonious socialist society, the plan encapsulates the entangled objectives of 'indigenous innovation, leapfrogging in priority fields, enabling development, and leading the future' (MLP S\&T) in order to realise 'the great renaissance of the Chinese nation' (MLP S\&T, preface). Thus, China's S\&T policy is part of a wider narrative about China's overall development, catch-up and renaissance. Further, the plan develops a vision for frontier technologies and scientific frontier issues in basic research, focusing on a number of priority areas such as renewables, the manufacturing industry, IT and software, core mathematics, manufacturing and (renewable) energies. For instance, the MLP S\&T emphasises the need to raise the capability of equipment design, manufacturing and integration, e.g. by promoting technological innovation, realising proprietary design and manufacturing high-end programmed machine tools and key components. Overall, China's innovation policy can be seen as integral to strengthening China's domestic innovation capacity, which is crucial to transforming China's economy beyond the export-oriented global factory model (Ernst 2013: 2). Aiming to transform China's S\&T system into a national innovation system, the plan also includes strategies for managing IPRs and standards, as well as the expansion of international and regional S\&T cooperation and exchange. Accordingly, in addition to this influential plan, a comprehensive policy framework has been developed with regard to IPRs and standards. This has gathered momentum since China's accession to the World Trade Organisation (WTO) in 2001 (Ernst 2013).

With regard to wind power, the 5YPS\&T Wind Power outlines critical areas requiring upgrading and prioritised strategic focus. Set within the guiding ideology of scientific development and indigenous innovation, and based on concerns that are raised in the plan regarding China's relative backwardness and continued dependence on foreign core technologies, this industry-specific plan indicates that a key priority in Chinese wind power has become the development of indigenous innovation in order to 'transform China from a large wind power nation into a strong wind power nation' and to ensure the 'healthy and sustainable development of China's wind power industry', and to catch up with foreign countries (5YP S\&T Wind Power). In order to improve wind turbine performance and wind power integration, software tools are considered critically important (5YP S\&T Wind Power; Kirkegaard 2015). Since software is 
composed of thousands of lines of source code, upgrading of software tools is closely related to basic research in algorithms and core mathematics. These are critical for understanding aerodynamics and aeroelasticity as well as the development of software simulation tools and testing equipment (5YP S\&T Wind Power). Accordingly, China must develop independent intellectual property rights (IPRs) for wind power design tools and software systems. Improvements in China's standardisation system and its adaptation to local conditions hinge on the improvement of wind power software tools (5YP S\&T Wind Power).

\section{Rapid Upgrading and Attempts to Reduce Dependence on Foreign Technologies}

China's wind turbine industry has realised a series of rapid technological advances and achievements, including the design of larger, variablespeed turbines with multi-MW capacities (1-5 MW), and attempts to move into large offshore projects (Klagge et al. 2012; Lewis 2013). In terms of component equipment manufacturing, Chinese companies are catching up; they are already boasting capabilities in the production of blades, gearboxes and electric control systems. The technological advancements of Chinese wind turbine and component manufacturers are also pinpointed in the 5YP S\&T Wind Power. Additionally, China has recently established a certification and standardisation system for the industry, and is working towards conforming to international standards as well as developing indigenous standards (Korsnes 2015; 5YP S\&T Wind Power; Ernst 2011; 2013).

Despite their long experience with heavy industry, Chinese wind turbine manufacturers (WTMs) started out without specific knowledge of wind turbine technologies. In order to quickly catch-up and develop capabilities, Chinese WTMs relied heavily on policies that would encourage transfer of foreign technologies, foreign direct investment (FDI) and cross-border technological learning in general (Klagge et al. 2012; Li 2010; Lewis 2013; Kirkegaard 2015). Over time, as Chinese WTMs, such as Envision and Goldwind, have improved their capabilities in wind turbine technologies and certification and standardisation, the traditional technology transfer mode of licensing has increasingly been overtaken by more cooperative innovation through collaborative design and co-development: through joint ventures and mergers and acquisition, establishment of overseas R\&D centres, and cross-border collaborative R\&D linkages (Lema et al. 2013; Lewis 2013; Klagge et al. 2012; Li 2010; Ru et al. 2012; Kirkegaard 2015). 
Yet quality issues and China's continued dependence on foreign core technologies remain a key concern in the 5YP S\&T Wind Power. This continued dependence is largely part explained by the legacy of technology transfer, foreign direct investment (FDI) and cross-border technological learning in Chinese wind power. The legacy of foreign technology licensing has laid the basis for a strategy of imitation and reverse engineering of imported technology (Lewis 2007; Lewis 2013; Klagge et al. 2012; Chen et al. 2014; Li 2010; Kirkegaard 2015; Lema et al. 2013; MLP S\&T). Most Chinese wind turbine manufacturers have based their wind turbines on mature foreign design licenses, and have often based their control systems on relatively mature control system technologies (hardware and software) acquired from foreign suppliers. Despite impressively rapid upgrading, China still lags behind in terms of basic research and indigenous development of core technologies (Kirkegaard 2015; Lewis 2012), such as software programmes in the turbine's main controls and simulation tools for developing and optimising new turbine designs. Accordingly, the 5YP S\&T Wind Power emphasises the need to upgrade and develop indigenous innovation capabilities in these areas as well as to engage in international collaborations and cross-disciplinary research on advanced software tools e.g. for wind turbine, blade and wind farm modelling/design and simulation (5YP S\&T Wind Power) in order to overcome what seems to constitute a 'software gap'. In turn, as software is composed by thousands of lines of source codes, the plan also emphasises the need to upgrade capabilities in basic research on algorithms and core mathematics to improve the aerodynamic design of wind turbines through the optimisation of aeroelastic codes, which are critical to design optimisation and certification of new and adapted turbines (5YP S\&T Wind Power; Kirkegaard 2015).

\section{The Role of Software in Control Systems and Simulation Tools for Global Competition}

China still lags behind in terms of independent, indigenous innovation and basic research into aerodynamics and aeroelastic design, testing and certification, core technologies (such as advanced control system software, including that for the independent pitching of blades) and simulation tools. It is also playing catch-up in relation to indigenous intellectual property of software tools, which are 'core' to the design and certification of new wind turbine designs (5YP S\&T Wind Power). China can compare its industry standard to that of the international standard series for wind turbine design (type/model) certification (the 
IEC-61400-22 standards series of the International Electro-Technical Commission) (Korsnes 2015).

Conventionally, standards are considered critical for economic performance, since they are considered critical tools for evaluating and comparing quality, for innovation and international trade, and the 'owners' of a standard can shape the path of technology development (Kirkegaard 2015; Korsnes 2015: 23). With a relatively short track record of wind power and certification, and with an initial focus on rapid quantitative growth, China has not yet fully engaged with the international standard:

testing new designs and selling turbines is possible without an international certificate. The reason for this is that complying to international standards early on can make technology development harder, as compliance requires much time and money and a higher degree of foreign involvement. (Korsnes 2015: 188-189)

To remedy its shortcomings, China is currently seeking to transform itself from being a mere standard-taker 'to become a co-shaper, and in some areas a lead shaper, of international standards' (Ernst 2013: 2 qtd. in Kirkegaard 2015: 305). The industry is pursuing a 'two-track approach', both attempting to adapt to international standards (set by the IEC) and develop Chinese domestic standards (Ernst 2011; Kirkegaard 2015; Korsnes 2015). As expressed by President Xi Jinping, whilst not excluding the potentiality of international collaboration, 'China would demand a bigger say in the rules and standards that govern global science and technology innovation' (President Xi Jinping in Sinosphere 2014 qtd. in Kirkegaard 2015: 305). While there has been some development in this area, it appears that China's success in developing domestic standards has been limited and whilst being accepted formally by international IEC standards, such acceptance has proven to be a challenge at the informal level, e.g. in ICE working groups and global, informal scientific circles (Kirkegaard 2015). In China's struggle to qualify as a standard co-shaper and even lead-shaper, development of indigenous software source codes in the turbine's main controls as well as simulation tools, has become critical.

A turbine's competitiveness is distinguished by its output performance, which relies on optimal aerodynamic design and optimal control. Whilst type 'certification is a matter of attempting to gain confidence from customers' (Interview with Chinese certification body in Kirkegaard 2015: 278) as it produces certainty of a specific power curve creating certainty of output (and economic performance) from the wind 
turbine - the quality and level of advanced technology of turbines is increasingly distinguished by their aeroelastic design, which has become a 'parameter of competitiveness' (Interview with aeroelastic scientific expert at DTU Wind Energy in Kirkegaard 2015: 290). Thus, 'even though they [wind turbines] look alike, they can be more or less advanced. A lot of what we are working at, that is actually building knowledge into the blades. Or into the entire wind turbine. To ensure that it has the best aerodynamic solution of all. The best response possible' (Interview withaeroelastic scientific expert at DTU Wind Energy in Kirkegaard 2015: 290). The aeroelastic design can help ascertain the degree of the turbine's 'elegant, advanced and intelligent' design, and it is therefore critical in global competition and for aligning with the ambition of China's scientific development plan. To ensure the 'elegant' design of a turbine, continuous optimisation of and research into control systems and simulation design tools is required, which in turn enables the continuous optimisation of the aeroelastic design of the turbine blades. That is, 'there are two ways to differentiate your company and technology, that is, through the blades [i.e., the aeroelastic design codes of the blade simulation tools] and the main control algorithm' as these together can optimise the power performance and reduce the cost of energy, which is a key parameter of quality and competitiveness (Interview with aeroelastic expert at DTU Wind Energy in Kirkegaard 2015: 228).

\section{Construing 'Algorithmic Quality' through Aeroelastic Codes and Regulation Principles}

To meet international certification standards and develop indigenous domestic standards, a simulation tool is required. This is due to the way in which certification of a wind turbine design consists of recursive processes of (1) computer calculations with a software simulation tool, (2) testing, and (3) documentation in what may be termed a 'certification triangle' (Interview with wind turbine design expert in Danish design house in Kirkegaard 2015: 273). The iterative process of the triangle hinges on the continuous optimisation of the relation between the loads $(\mathrm{L})$ on the turbine from the forces resulting from the wind, the aerodynamic design (A), and the control system (C)/controller/regulation principle (LAC) during simulation and testing (Interview with design expert in a Danish design house in Kirkegaard 2015). The core algorithm of the simulation tool is an aeroelastic code that ensures the optimal relation between LAC. It also contains the control's core algorithm (the regulation principle, including pitch regulation of the blades in accordance 
with the changing wind speeds). The aeroelastic code in the simulation tool is thus critical for designing, simulating, testing and certifying new wind turbines in accordance with international standards (Interview with design expert in a Danish design house in Kirkegaard 2015: 273).

The principles of the aeroelastic design are in turn encoded into software algorithms of the simulation tool. In particular, the aeroelastic code constitutes the 'core' of the simulation or what is popularly termed 'the stomach' of the turbine (aeroelastic scientific expert at DTU Wind Energy in Kirkegaard 2015: 290-291). The aeroelastic code contains information about the aeroelastic design and also the regulation principle of the main control in order to ensure the optimised relation between loads, aerodynamics and the control (LAC). This means that the optimised aeroelastic design of a wind turbine is closely related to how the turbine is regulated and controlled. Described as the turbine's 'spine' or 'central nervous system' - positioned at the centre of the thousands of lines of source codes and which coordinates all information from the different components to regulate the wind turbine in the most safe and efficient way - the main control also contains information about the aeroelastic design of the turbine. The software algorithms of the simulation tool and of the main control are thus closely intertwined, in 'algorithmic quality' (Kirkegaard 2015: 291); that is, aeroelastic software codes construe a boundary between 'inferior' and 'superior' turbines.

\section{Entangled Controversies over IPRs and Standards and Black-boxes within Black-boxes}

As Chinese certification bodies and wind turbine manufacturers continue to build capabilities and experiment with development of simulation tools and aeroelastic codes, the role and position of Chinese actors as 'inferior partners' is increasingly contested by Chinese actors. Yet, despite having teams dedicated to developing aeroelastic codes, China still lacks a substantial research background in aerodynamics, which means that 'they still need to develop an aeroelastic code' (Interview with aeroelastic scientific expert at DTU Wind Energy in Kirkegaard 2015: 294). Thus, while software algorithms in main controls and in simulation tools produce associations of sustainability in comprehensive terms, they also produce a competitive space as algorithms de- and re-configure competitive dynamics between Chinese and foreign actors.

This is reflected in how competitive games have occurred as Chinese actors seek to gain access to the core algorithms of different foreign software tools. Regarding the main control, 'a lot of people want our 
source codes for our program. But we don't give it away' (Interview with aeroelastic scientific expert at DTU Wind Energy in Kirkegaard 2015: 228). Since core algorithms of the wind turbine's main control are 'simply a factor of competitiveness' for control system companies (Interview with aeroelastic scientific expert at DTU Wind Energy in Kirkegaard 2015: 228), and fearing IPR infringement, the companies 'black-box' the source codes, sometimes through legal IPRs, and sometimes through other means such as trade secrets (via technical locks and cryptations) (Interviews with foreign control system suppliers in Kirkegaard 2015). As Chinese companies have built up new capabilities and aim for independence and empowerment, also within control systems, they require greater mutual knowledge sharing, which has led some foreign software companies to modularise their source codes for Chinese companies to access carefully selected codes (and thus not the 'core' algorithms):

These are the ultimate interests of the game, the reason why the Chinese companies ask the [...] companies to open the source [codes]. Chinese companies do not want their own control system controlled by others, they hope to change the ownership rights, to optimise [make adaptations to the codes].' (Interview with foreign control system supplier in Kirkegaard 2015: 256)

The simultaneous dynamics of competition and collaboration are configured over the issue of access to the main control's core algorithms, and entangled in a controversy over IPRs. At the same time, this controversy around core algorithms is entangled in a controversy over certification and standardisation. As most Chinese wind turbine manufacturers or certification agencies have not developed an aeroelastic code themselves, they often buy a simulation tool, for instance commercial load calculation tool called Bladed, which is used in mechanical simulations. Bladed is developed and sold by Garrad Hassan (now Det Norske Veritas Germanischer Lloyd or DNV GL) (Interview with wind turbine design expert in Danish design house in Kirkegaard 2015). To control and document that the simulations/calculations fit with actual measurements in the test element of the certification triangle, a parallel simulation tool is needed to check whether 'you come up with results [in the test] which differ widely [from the calculated simulations] on critical points'. (Interview with wind turbine design expert in Danish design house in Kirkegaard 2015: 293). However, it is not only the core algorithm of the main control's pitch regulation principle, which is part of the simulation tool, that is black-boxed, but also the aeroelastic codes. Bladed thus constitutes 'black-boxes within black-boxes,' 'meaning that nobody actually knows how it calculates' (Interview with wind turbine 
design expert in Danish design house in Kirkegaard 2015: 293) if they have not developed an indigenous tool themselves. With such blackboxes within black-boxes, Chinese customers risk only being able to 'use the tool' without being able to make adaptations and optimisations, or develop indigenous aeroelastic codes. Thus, access to the source codes of the main control becomes obsolete in the lack of indigenous aeroelastic codes and other critical core algorithms, since it is impossible to make sense of the tools and the codes 'if you don't understand the basic behavior of the turbine' (Interview with aeroelastic scientific expert at DTU Wind Energy in Kirkegaard 2015: 255).

Performing 'algorithmic quality', and allocating 'inferior' and 'superior' roles and positions to different actors, in terms of more or less advanced simulation tools and their aeroelastic codes, a competitive space is being constructed around critical core algorithms. As Chinese actors oppose their framing as 'inferior', however, a controversy unfolds over IPRs and certification and standardisation, in which seemingly mundane artefacts, such as software simulation tools and their algorithms, create power struggles and configure relations. As Chinese certification bodies want 'to reach an equal status[...] [The Chinese actors] want to be internationally accredited' (Interview with Chinese certification body in Kirkegaard 2015: 302).

Struggles are taking place around IPR and standardisation, entangled in a Chinese political concern for industrial upgrading and indigenous innovation to align with scientific development. This has made Sinoforeign supply chain relations, as well as relative positions, roles and identities, unstable and fragile. Meanwhile, algorithms are co-configuring relations and competitive dynamics, as they are critical to ensuring 'quality' and to framing wind turbines as intelligent and advanced - through 'algorithmic quality' - which is critical in global competition and for inclusion in international research collaborations (Kirkegaard 2015). As such, algorithms are core actors in the development of China's potential turn to quality in the context of scientific developmentalism.

\section{Discussion: Agency and the Potential of China's Experimental Governance}

This article set out to explore whether and how a constructivist lens within the Anthropology of Markets and a Mapping Controversies approach could help shed light on some of the micro-processes of China's industrial development. The analysis has showed how software 
algorithms have become constituted as political entities that engender controversy and negotiations over access and exclusion, over IPRs and certification and standardisation, and fundamentally over the right to define quality as well as relative Sino-foreign positions, roles, and identities in the global value chain. The political constitution of algorithms derives from the entangledness of the industry in the Chinese socio-technical imaginary of scientific and sustainable development, which transforms strategic and largely state-controlled industries such as the wind turbine industry into a contested space. The paradoxical dynamics of simultaneous collaborative and competitive forces in Sinoforeign relations, due to role ambiguity, are marked by a high degree of fragility and volatility.

By shedding light on how material and seemingly mundane entities such as algorithms at the micro-level may tell a broader macro-story of the socio-technical struggles inherent in China's scientific developmentalism, the article illustrates how a constructivist lens can indeed qualify our understanding of some of the micro-dynamics of global competition and China's 'turn to quality'. Further, through its microprocessual account of the changing nature of Sino-foreign competitive and highly negotiated relations, it also sheds light on a particularly Chinese pragmatic and experimental mode of industrial policy. That is, in the development of China's wind power market, the Chinese Government has pursued a policy of radical non-intervention in the wind power market by first allowing a potentially self-disruptive quality crisis to emerge, followed by intervention and fine-tuning of the industry to realign the market with a sustainable, scientific development through a turn to quality.

Thus, indirectly, the article aligns with and sheds new light on the literature on China's adaptive, fragmented, experimental and pragmatic style of governance (cf. Heilmann 2008, 2009, 2011; Heilmann and Perry 2011; Korsnes 2014; Goldstein 1996). It also indicates how a relational and micro-processual, and non-structuralist constructivist account can provide an agency-filled and possibility-rich account where relations, roles, positions and identities are being negotiated and re-shuffled, and where seemingly mundane artefacts also can play a critical role in the formation of relations and structures. This breaks with the somewhat structural, functionalistic and hierarchical accounts generally found in the China literature. While the literature on fragmented authoritarianism (e.g. Lieberthal 2004) and on China's particular 'variety of capitalism' (e.g. Hall and Soskice 2001; McNally 2007; Witt 2010) has provided rich 
insights into China's institutional structures, this literature largely abides by a path-dependent account of binding structures and vested interests. This article instead offers a micro-processual and relational account by tracing socio-technical struggles and controversies over seemingly mundane artefacts such as software algorithms, shedding light on how larger patterns and structures are malleable as relations are being de- and reconfigured through continuous contestation and negotiation. As actors in this way possess a high degree of agency, capable of constructing and moulding relations and even the institutions that govern and affect them, the article aligns more strongly with accounts of China's experimental governance mode and Chinese variegated capitalism (Peck and Theodore 2007; Peck and Zhang 2013; Redding and Witt 2006; Zhang and Peck 2014). These offer an account of emerging and continuously dissolving structures rather than binding, path-dependent institutional complementarities and coherence.

This account of the flexible adaptive moves made by the Chinese government illustrates a 'structured uncertainty' in China's fragmented governance mode. According to Breznitz and Murphree, this structured uncertainty, which is characteristic of China's fragmented authoritarianism, may be exactly what has enabled China's unique advantage, economic miracle and national innovation system $(2011: 8,20)$. Thus, taking the example of scientific development and the ambition of indigenous innovation, it can be argued that the Chinese high-technology development path has differed drastically from the official one planned and hoped for by Chinese central government (Breznitz and Murphree 2011). While maintaining an official overarching goal of indigenous innovation, the pragmatism of Chinese governance has allowed the government to flexibly and ambiguously interpret and re-adjust its own goals when meeting challenges and stages of impasse. Pragmatism has thus enabled China to re-interpret its policy of indigenous innovation, allowing it to run 'as fast as possible in order to remain at the cusp of the global technology frontier without actually advancing the frontier itself' (Breznitz and Murphree 2011:3), allowing it to overcome the impasse of quality struggles and self-disruption.

Conversely, a too-rigid interpretation of China's scientific developmentalism and indigenous innovation can create self-disruptive power struggles in Sino-foreign relations that could destabilise the entire industry. As such, the Chinese state displays strategic 'navigational skills' (Korsnes 2014: 196) and an 'impressive ingenuity in nurturing new industries' as challenges emerge (Korsnes 2014: 195). Thus, para- 
doxically, while China's 'pragmatics of green marketisation' (Kirkegaard 2015) helped produce a quality crisis - threatening to delegitimise the Chinese pragmatics of marketisation - this same pragmatics of green marketisation is likely to enable the 'turn to quality' and experimental learning. While the 'turbine wave attack' has threatened to destabilise the entire wind power market, it may in fact be China's structured uncertainty and fragmented authoritarianism that makes it possible for the industry to establish new markets, break free from constraining relations, and change direction when needed. In this way, the article shows how China's particular mode of variegated capitalism and matrix muddle makes the seemingly paradoxical path of Chinese wind power 'logical' within a Chinese developmental perspective.

\section{Conclusion}

Core technologies - in particular software tools and their algorithmic contents - have become increasingly critical and politicised in China's potential 'turn to quality' in wind power, since core algorithms have become constituted as critical for the optimisation, design and certification of wind turbines following China's 'turbine wave attack'. The turn to quality has put core algorithms centre stage for contestation, as collaborative relations around software between Chinese and foreign actors have become more prone to power struggles. In turn, China's highly politicised wind power market and its fragmented, experimental nature renders the relative positioning of firms and roles, positions and identities in the global value chain volatile, fragile and unpredictable.

This account has portrayed China's industrial governance structures as political, fragile and potentially self-disruptive. While pointing to the political nature of software algorithms, this article has posited a possibility- and agency-filled account, an account that does not conceive of actors as embedded within path-dependent institutional structures and hierarchies. Instead, it describes creative and experimental action through a relational, pragmatist, socio-technical and highly empiricist lens from an STS perspective. The constructivist perspective of the Anthropology of Markets within STS can help shed light on the agency and micro-dynamics of the industry in the developmental context of China's experimental and pragmatic market construction. By tracing relations and mapping controversies around core algorithms, this article has shown how 'micro-relations' may reflect a broader story of Chinese industrial development and fragmented, experimental governance. 
Julia Kirch Kirkegaard is a Postdoctoral Researcher at the Technical University of Denmark (DTU), Department of Wind Energy, INP Section (Integration and Planning). This article is based on Kirkegaard's (2015) PhD from Copenhagen Business School, Department of Business and Politics, which was funded by the Sino-Danish Centre for Research and Education (SDC) in Beijing. Email: jukk@dtu.dk

\section{NOTES}

1 The notion of scientific development has become a central doctrine in China and was enshrined in Chinese Communist Party doctrines, alongside the notion of sustainable development, in 2007 (Christensen 2013: 86).

\section{REFERENCES}

Bloomberg, New Energy Finance 2012. 'Will China's new Renewable Portfolio Standard boost project development?' (11 May). Renewable Energy: Research Note.

Breznitz, Dan, and M. Murphree 2011. Run of the Red Queen: Government, Innovation, Globalization, and Economic Growth in China. New Haven: Yale University Press.

Brødsgaard, Kjeld Erik 2002. 'Institutional Reform and the Bianzhi System in China'. The China Quarterly 170: 361-386.

Callon, Michel (ed.) 1998. The Laws of the Markets. Oxford: Blackwell Publishers.

Callon, Michel and Koray Çalişkan 2009. 'Economization, Part 1: shifting attention from the economy towards processes of economization'. Economy and Society 38 (3): 369-398.

Callon, Michel and Koray Çalişkan 2010. 'Economization, Part 2: a research programme for the study of markets'. Economy and Society 39(1): 1-32.

Chen, Y. and Kantai Rong, Lan Xue, Laijun Luo 2014. 'Evolution of collaborative innovation network in China's wind turbine manufacturing industry'. International Journal of Technology Management 65 (1/2/3/4): 262-299.

Cherni, Judith A., and Joanna Kentish 2007. 'Renewable energy policy and electricity market reforms in China'. Energy Policy 35: 3616-3629.

Christensen, Nis Høyrup 2013. Shaping Markets: A Neoinstitutional Analysis of the Emerging Organizational Field of Renewable Energy in China. PhD thesis. Frederiksberg: Copenhagen Business School.

Ernst, Dieter 2011. 'Toward Greater Pragmatism? China's Approach to Innovation and Standardization'. Policy Brief 18: 1-7.

Ernst, Dieter 2013. 'Standards, Innovation, and Latecomer Economic Development: A Conceptual Framework'. East-West Center Working Papers, Economics Series 134: 1-21.

Fan, C. Cindy 2006. 'China's Eleventh Five-Year Plan (2006-2010): From “Getting Rich First" to "Common Prosperity"'. Eurasian Geography and Economics 47 (6): 708-723.

García, Clara 2013. 'Policies and Institutions for Grid-Connected Renewable Energy: "Best Practice" and the Case of China'. Governance: An International Journal of Policy, Administration, and Institutions 26(1): 119-146. 
Goldstein, Steven M. 1996. 'The Political Foundations of Incremental Reform'. In A. Walder (ed.) China's Transitional Economy. Oxford: Oxford University Press: 143-169.

GWEC (Global Wind Energy Council) 2016. Global Wind Report. Annual Market Update $-2015$.

Hall, Peter A., and David Soskice 2001. Varieties of Capitalism: The Institutional Foundations of Comparative Advantage. Oxford: Oxford University Press.

Heilmann, Sebastian 2005. 'Regulatory Innovation by Leninist Means: Communist Party Supervision in China's Financial Industry'. The China Quarterly 181: 1-21.

Heilmann, Sebastian 2008. 'From Local Experiments to National Policy: The Origins of China's Distinctive Policy Process'. The China Journal 59: 1-30.

Heilmann, Sebastian 2009. 'Maximum Tinkering under Uncertainty: Unorthodox Lessons from China'. Modern China 35(4): 450-462.

Heilmann, Sebastian 2011. 'Policy Making through Experimentation: The Foundation of a Distinctive Policy Process'. In S. Heilmann and E. J. Perry (eds.) Mao's Invisible Hand: The Political Foundations of Adaptive Governance in China. Harvard: Harvard Contemporary China Series: 62-101.

Jasanoff, Sheila, and Sang-Hyun Kim 2009. 'Containing the atom: Sociotechnical imaginaries and nuclear power in the United States and South Korea'. Minerva 47: 1119-146.

Kirkegaard, Julia Kirch 2015. Ambiguous Winds of Change - Or Fighting Against Windmills in Chinese Wind Power: Mapping Controversies over a Potential Turn to Quality in Chinese Wind Power. PhD thesis. Frederiksberg: Copenhagen Business School.

Kirkegaard, Julia Kirch Forthcoming. Rapid upgrading through experimental (self-)disruptive impasse. The case of China's wind turbine industry. Paper to be presented at 'International Conference: Innovation and Social Development in Guangzhou', Guangzhou, 12-15 June 2016.

Kirkegaard, Julia Kirch, and Koray Caliskan Forthcoming. Winning the Wind Back during a Market-Quake: The Politics of Wind Power Marketization in China. Paper to be presented at 'Workshop on (Im)Possible markets: Putting market studies to work', St Andrews, 8-10 June 2016.

Klagge, Britta, and Liu Zhigao, Pedro Campos Silva 2012. 'Constructing China's wind energy innovation system'. Energy Policy 50: 370-382.

Korsnes, Marius 2014. 'Fragmentation, Centralisation and Policy Learning: An Example from China's Wind Industry'. Journal of Current Chinese Affairs 43(3): 175-205.

Korsnes, Marius 2015. 'Chinese Renewable Struggles: Innovation, the Arts of the State and Offshore Wind Technology'. PhD thesis. Trondheim, Norway: NTNU.

Latour, Bruno 2005. Reassembling the Social: An Introduction to Actor-Network-Theory. New York, NY: Oxford University Press.

Lema, Rasmus, and Axel Berger, Hubert Schmitz 2013. 'China's Impact on the Global Wind Power Industry'. Journal of Current Chinese Affairs 42(1): 37-69.

Lema, Adrian, and Kristian Ruby 2007. 'Between fragmented authoritarianism and policy coordination: Creating a Chinese market for wind energy'. Energy Policy 35: 3879-3890.

Lewis, Joanna I. 2013. Green innovation in China. China's Wind Power Industry and the Global Transition to a Low-Carbon Economy. New York: Columbia University Press.

$\mathrm{Li}$, Jun 2010. 'Decarbonising power generation in China - Is the answer blowing in the wind?' Renewable and Sustainable Energy Reviews 14: 1154-1171.

Li, Cun-bin, and Peng Li, Xia Feng 2014. 'Analysis of wind power generation operation management risk in China'. Renewable Energy 64: 26-275.

Liao, Cuiping, and Jochem Eberhard, Yi Zhang, Nida R. Farid 2010. 'Wind power development and policies in China'. Renewable Energy 35: 1879-1886. 
Lieberthal, Kenneth 2004. 'The organization of political power and its consequences: The view from the outside'. In Kenneth Lieberthal (ed.) Governing China: From Revolution Through Reform. 2nd ed. New York: W.W. Norton \& Co.: 171-205.

McNally, Christopher A. 2007. 'China's capitalist transition: The making of a new variety of capitalism'. Comparative Social Research 24: 177-203.

Mertha, Andrew 2009. 'Fragmented Authoritarianism 2.0: Political Pluralization in the Chinese Policy Process'. The China Quarterly 200: 995-1012.

Peck, Jamie, and Nik Theodore 2007. 'Variegated capitalism'. Progress in Human Geography 31(6): 731-772.

Peck, Jamie, and Jun Zhang 2013. 'A variety of capitalism...with Chinese characteristics?' Journal of Economic Geography 13: 357-396.

Redding, Gordon, and Michael. A. Witt 2006. 'The "Tray of Loose Sand": A Thick Description of the State-Owned Enterprise Sector of China Seen as a Business System'. Asian Business \& Management 5: 87-112.

Yu, James, and Fuxing Ji, Ling Zhang, Yushou Chen 2009. 'An over painted oriental arts: Evaluation of the development of the Chinese renewable energy market using the wind power market as a model'. Energy Policy 37: 5221-5225.

Zhang, Jun and Jamie Peck 2014. 'Variegated Capitalism, Chinese Style: Regional Models, Multi-scalar Constructions'. Regional Studies.

\section{Policies and plans}

Renewable Energy Law 2005/2006, Standing Committee of the National People's Congress (NPC): Renewable Energy Law of the People's Republic of China. Adopted at the 14th Meeting the Standing Committee of the Tenth National People's Congress on February 28, 2005 http://www.ccchina.gov.cn

MLP S\&T, State Council, The Central People's Government of the People's Republic of China: The National Medium- and Long-Term Program for Science and Technology Development (2006-2020), 2006. http:/ / www.gov.cn/jrzg/2006-02/09/content_183787. htm

5YP S\&T Wind Power (2012) (in Chinese), State Council, The Central People's Government of the People's Republic of China: The 12th 5-Year-Plan for the Scientific Development of Wind Power (2012): 197. (http://www.most.gov.cn/fggw/zfwj/ zfwj2012/201204/t20120424_93884.htm) 